\title{
Article \\ A Redox-Neutral, Two-Enzyme Cascade for the Production of Malate and Gluconate from Pyruvate and Glucose
}

\author{
Ravneet Mandair ${ }^{1}$, Pinar Karagoz ${ }^{1,2}$ and Roslyn M. Bill ${ }^{1, * \mathbb{D}}$ \\ 1 College of Health and Life Sciences, Aston University, Birmingham B4 7ET, UK; \\ ravmandair92@hotmail.com (R.M.); p.karagoz@ucl.ac.uk (P.K.) \\ 2 Department of Biochemical Engineering, University College London, Gower Street, London WC1E 6BT, UK \\ * Correspondence: r.m.bill@aston.ac.uk; Tel.: +44-12-1204-4274
}

check for updates

Citation: Mandair, R.; Karagoz, P.; Bill, R.M. A Redox-Neutral, Two-Enzyme Cascade for the Production of Malate and Gluconate from Pyruvate and Glucose. Appl. Sci. 2021, 11, 4877. https://doi.org/ 10.3390/app11114877

Academic Editor: Francesca Scargiali

Received: 22 March 2021

Accepted: 24 May 2021

Published: 26 May 2021

Publisher's Note: MDPI stays neutral with regard to jurisdictional claims in published maps and institutional affiliations.

Copyright: (c) 2021 by the authors. Licensee MDPI, Basel, Switzerland. This article is an open access article distributed under the terms and conditions of the Creative Commons Attribution (CC BY) license (https:// creativecommons.org/licenses/by/ $4.0 /)$.

\begin{abstract}
A triple mutant of $\mathrm{NADP}(\mathrm{H})$-dependent malate dehydrogenase from thermotolerant Thermococcus kodakarensis has an altered cofactor preference for $\mathrm{NAD}^{+}$, as well as improved malate production compared to wildtype malate dehydrogenase. By combining mutant malate dehydrogenase with glucose dehydrogenase from Sulfolobus solfataricus and $\mathrm{NAD}^{+} / \mathrm{NADH}$ in a closed reaction environment, gluconate and malate could be produced from pyruvate and glucose. After $3 \mathrm{~h}$, the yield of malate was $15.96 \mathrm{mM}$. These data demonstrate the feasibility of a closed system capable of cofactor regeneration in the production of platform chemicals.
\end{abstract}

Keywords: enzymatic cascade reaction; malate production; malate dehydrogenase; glucose dehydrogenase

\section{Introduction}

Platform chemicals are molecules that can be used to make a variety of industrially valuable products including solvents, polymers, pharmaceuticals and foods [1]. Most commercial platform chemicals are mass-produced from petrochemical processes that use fossil fuels as the starting raw materials [2], typically via low-cost, high-volume commodity chemicals (methanol, ethylene, propene, butadiene, benzene, toluene and xylene) [3]. While recent advances have enabled the use of renewable approaches on an industrial scale (such as the production of polylactide and polyethylene from ethylene and biomass-derived lactic acid [4]), the sustainable production of a wider range of platform chemicals is a priority given global concerns about the environment, limited resources, and high oil prices [3,5].

One platform chemical in high global demand is malic acid. Malic acid, along with other four-carbon diacids (such as succinic and fumaric acids), was reported as one of the top value-added chemicals from biomass in a 2004 U.S. Department of Energy report [6]. Four-carbon diacids can be converted into 1,4-butanediol which can be further converted into high-value products such as tetrahydrofuran, an important material for polymer production. The current commercial production of malic acid is via the chemical hydration of petrochemically derived maleic/fumaric acid [7], but advances in the field of metabolic engineering have renewed interest in its bio-based production [8]. Natural high-capacity malic acid producers such as Aspergillus flavus are not well-suited to industrial use due to their physiological constraints [3] and the associated generation of aflatoxin (a carcinogen). A particular concern is the need to control multiple metabolic pathways that lead to the formation of unwanted intermediates [9], thereby reducing conversion efficiencies.

Cell-free metabolic engineering uses purified enzyme systems or crude cell lysates in the synthesis of complex biomolecular commodities, thereby overcoming limitations associated with using whole cells [3]. However, the high cost of processes involving enzyme purification and the need to supplement reactions with the necessary cofactors are current challenges. The nicotinamide nucleotides $\mathrm{NAD}^{+}$and $\mathrm{NADP}^{+}$are used by most redox enzymes, and their balance is crucial in cell-free enzymatic pathways which lack metabolic regulation from living cells [3]. Developing cascades consisting of multiple 
enzymes in cell-free pathways is a recent development [10]. This has led to developments in the design of cell-free systems in which cofactors can be recycled on account of their high costs [11]. Glucose dehydrogenase (GDH), along with formate dehydrogenase (FDH), are the two most widely used enzymes for cofactor recycling in industrial/commercial processes, with GDH from the Bacillus species showing the highest activity and stability, leading to its wide applications in industry [12].

$\mathrm{NADP}(\mathrm{H})$-dependent malate dehydrogenase from the thermophilic archaeon Thermococcus kodakarensis, catalyzes the $\mathrm{HCO}_{3}{ }^{-}$independent reductive carboxylation of pyruvate to malate and produces lactate as a by-product. Its application in artificial enzymatic cascades that use NADH as a cofactor is now possible following directed evolution to alter its cofactor preference from NADPH to NADH [13]. A triple mutant was identified that exhibited a sixfold higher $\mathrm{k}_{\mathrm{cat}} / \mathrm{K}_{\mathrm{M}}$ for $\mathrm{NAD}^{+}$than the wildtype enzyme together with increased malate (and lower lactate) yields. The triple mutant enzyme (hereafter referred to as $\mathrm{MDH}^{*}$ ) catalyzed pyruvate carboxylation with NADH to give a 1.2 times higher yield of malate than the wildtype enzyme with NADPH [13].

We previously immobilized purified recombinant GDH from Sulfolobus solfataricus onto novel, hierarchically structured macroporous-mesoporous silica supports and produced gluconic acid from both glucose and bread waste hydrolysate using $\mathrm{NAD}^{+}$as a cofactor. The aim of the present study was to use GDH and $\mathrm{MDH}^{*}$ in a closed system capable of cofactor regeneration in the production of malate from pyruvate (Supplementary Materials, Figure S1). We hypothesized that $\mathrm{MDH}^{*}$ would use the cofactor byproduct of GDH-facilitated gluconic acid production from glucose to catalyze the conversion of pyruvate to malate via $\mathrm{NADH}$, leading to its regeneration in the process.

\section{Materials and Methods}

\subsection{Microorganisms and Enzyme Production}

Expression-the gene encoding $\mathrm{MDH}^{*}$ from Thermococcus kodakarensis (GenBank accession number BAE47514.1) was synthesized and cloned into pET-30a via NdeI and BamHI at the $5^{\prime}$ and $3^{\prime}$ restriction sites, respectively. The full-length gene encoding 3 mutations (R221G, K228R and I310V) was synthesized by GenScript with the sequence optimized for expression in E. coli and the vector was transformed into BL21-DE3 competent cells. Cells were grown in LB media supplemented with $50 \mu \mathrm{g} / \mathrm{mL}$ kanamycin and grown at $37^{\circ} \mathrm{C}$ and $220 \mathrm{rpm}$ to $\mathrm{A}_{600}=0.6 .1 \mathrm{mM}$ (final concentration) IPTG (isopropyl $\mathrm{\beta}$-D-1thiogalactopyranoside) was used for induction and the cells were grown at room temperature for $18 \mathrm{~h}$ at $220 \mathrm{rpm}$.

Purification-cell pellets were obtained by centrifugation and re-suspended in $100 \mathrm{mM}$ HEPES pH 7.5, $200 \mathrm{mM} \mathrm{MgCl} 2,10 \%$ glycerol. Cell lysis was carried out using a cell disruptor system (Bandelin, SONOPULS, Berlin, Germany), followed by heat treatment at $70^{\circ} \mathrm{C}$ for $30 \mathrm{~min}$. Cellular debris was removed by centrifugation, and the crude lysate was bound overnight to Ni-NTA resin (Qiagen, Hilden, Germany) and eluted with buffer containing $500 \mathrm{mM}$ imidazole, $100 \mathrm{mM}$ HEPES pH 7.5, $200 \mathrm{mM} \mathrm{MgCl} 2,10 \%$ glycerol. The protein was then dialyzed into $100 \mathrm{mM}$ HEPES pH 7.5, $200 \mathrm{mM} \mathrm{MgCl}_{2}, 10 \%$ glycerol. Fractions containing $\mathrm{MDH}^{*}$ were pooled and their protein concentration was determined using the bicinchoninic acid assay (BCA; Reagent Compatible BCA Assay Kit, ThermoFisher Scientific, Waltham, MA, USA) and a Nanodrop device (ThermoFisher Scientific, Waltham, MA, USA). Samples were snap-frozen in liquid nitrogen and stored at $-80^{\circ} \mathrm{C}$. GDH used in this study was expressed, purified, and characterized as previously described [14].

\subsection{Enzyme Activity Assays}

$\mathrm{MDH}^{*}$ activity was assayed in $500 \mathrm{mM}$ HEPES pH 7.5, $5 \mathrm{mM} \mathrm{NH}_{4} \mathrm{Cl}, 0.5 \mathrm{mM} \mathrm{MnCl}_{2}$, $30 \mathrm{mM}$ pyruvate, $85 \mathrm{mM} \mathrm{NaHCO}_{3}$ and $1 \mathrm{mM} \mathrm{NADH}$. Unless otherwise stated, the activity assay for $\mathrm{MDH}^{*}$ was conducted in 96-well plates in a FLUOstar Omega Microplate Reader fitted with an atmospheric control unit (allowing full control and regulation of oxygen and carbon dioxide within the microplate reader chamber) at $55{ }^{\circ} \mathrm{C}$ for $2 \mathrm{~h}$ at $15 \% \mathrm{CO}_{2}$ and 
$5 \% \mathrm{O}_{2}$. The activity of both $\mathrm{MDH}^{*}$ and GDH (produced as described previously [14]) was detected by monitoring the $\mathrm{NAD}^{+}$concentrations of the supernatants with a plate reader at $340 \mathrm{~nm}$. Optimization studies were performed using MATLAB 2019a.

\subsection{Determination of Kinetic Constants}

The kinetic constants for $\mathrm{MDH}^{*}$ were determined by measuring the reaction rates at regular time intervals and different substrate levels $(0-75 \mathrm{mM}) . \mathrm{K}_{\mathrm{M}}$ and $\mathrm{V}_{\max }$ values were calculated from Lineweaver-Burk plots.

\subsection{HPIC Analysis}

Known standard concentrations of substrates/products were analyzed via HPIC to produce standard curves. These standard curves were then used to calculate the unknown concentrations of chemicals of interest. HPIC was performed using a Dionex ${ }^{\mathrm{TM}}$ Integrion $^{\mathrm{TM}}$ HPIC $^{\text {TM }}$ System (Thermo Fisher Scientific, Waltham, MA, USA). Unless otherwise stated, all samples were diluted ten times and detected under reaction conditions of $5 \mathrm{mM}$ eluent $(\mathrm{NaOH})$ at $30{ }^{\circ} \mathrm{C}$ at a $0.38 \mathrm{~mL} / \mathrm{min}$ flow rate. It was not possible to analyze glucose, gluconate or lactate with HPIC, and alternative chemical and enzymatic approaches were insufficiently sensitive. Pyruvate and malate were detectable in $2 \mathrm{~mL}$ reactions.

\section{Results}

\subsection{Purity and Activity of Recombinant $M D H^{*}$}

In building an enzyme cascade, the use of thermophilic enzymes has the potential to improve enzyme stability and therefore reduce costly enzyme purification. As we previously demonstrated, recombinant thermophilic GDH can be purified in a single step after initial heat treatment at $70^{\circ} \mathrm{C}$ for $30 \mathrm{~min}$ [14]. In this study, we also produced recombinant thermophilic $\mathrm{MDH}^{*}$ in order to couple its activity with that of GDH. Following heat treatment and affinity purification, $\mathrm{MDH}^{*}$-containing fractions were analyzed by SDSPAGE to determine protein purity. Figure 1 shows that purified recombinant $\mathrm{MDH}^{*}$ (which contained a decahistidine tag and linker with a combined molecular weight of $50 \mathrm{kDa}$ ) was $>95 \%$ pure. Protein-containing fractions were analyzed by BCA, pooled, and used immediately in experiments or snap-frozen prior to storage at $-80{ }^{\circ} \mathrm{C}$.

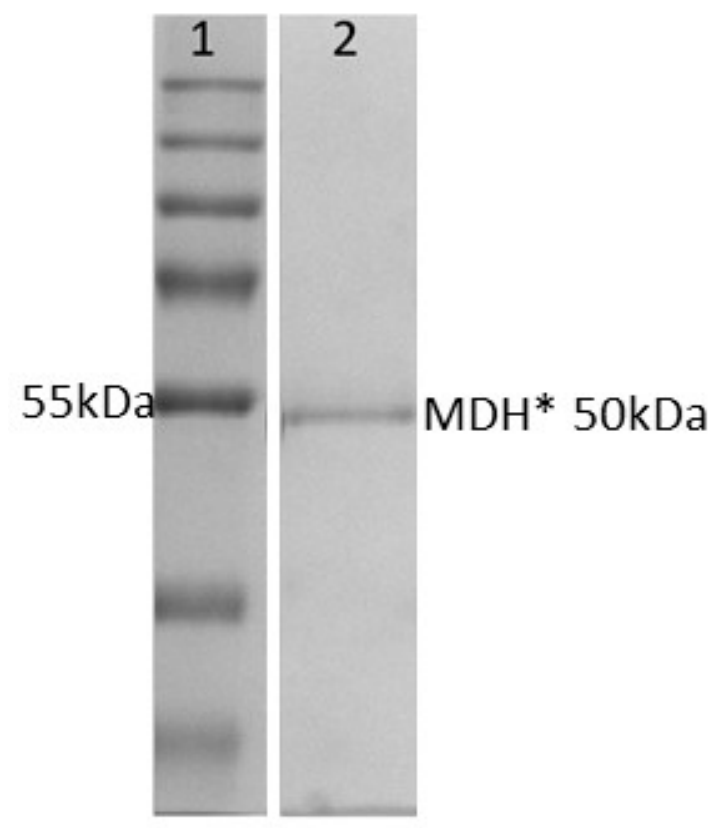

Figure 1. SDS-PAGE analysis of purified MDH*. Lane 1 shows molecular markers, and lane 2 is $\mathrm{MDH}^{*}$ purified by Ni-NTA affinity chromatography. 


\subsection{Effect of GDH Buffer Components on the Activity of $M D H^{*}$}

In order to identify reaction conditions that would support both enzymes in a onepot cascade reaction, it was necessary to analyze the effect on $\mathrm{MDH}^{*}$ activity of buffer components required for optimum GDH activity. The assay reagents needed for the two different enzymes varied, with some being used at different concentrations whilst others are only needed for one enzyme and not the other (Table 1). In particular, $\mathrm{MDH}^{*}$ activity assays require additional assay reagents in comparison to GDH, as well as atmospheric control (Table 1).

Table 1. Standard assay conditions for GDH and $\mathrm{MDH}^{*}$.

\begin{tabular}{|c|c|}
\hline GDH Standard Assay Conditions at $55^{\circ} \mathrm{C}$ & $\mathrm{MDH}^{*}$ Standard Assay Conditions at $55^{\circ} \mathrm{C}$ \\
\hline $\begin{array}{c}\text { No atmospheric control required } \\
100 \mathrm{mM} \text { HEPES pH } 7.5 \\
2.5 \% \text { glycerol } \\
30 \mathrm{mM} \mathrm{MgCl}_{2} \\
100 \mathrm{mM} \mathrm{glucose} \\
5 \mathrm{mM} \mathrm{NAD}^{+}\end{array}$ & 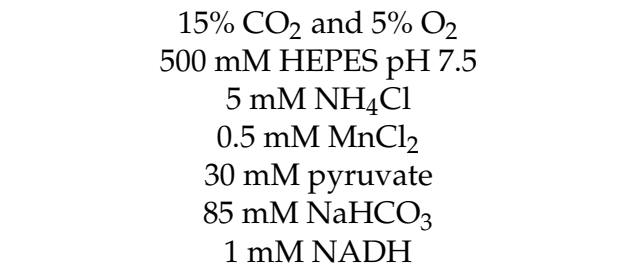 \\
\hline
\end{tabular}

The most significant effect was seen when the HEPES concentration was reduced from $500 \mathrm{mM}$ to $100 \mathrm{mM}$ (Figure 2), which is the concentration used in the GDH buffer (Table 1). As a result, the activity of $\mathrm{MDH}^{*}$ reduced by $20 \%$ (Figure 2). In contrast, the addition of glycerol, glucose, and $\mathrm{MgCl}_{2}$ into the $\mathrm{MDH}^{*}$ reaction mixture had no significant effect on $\mathrm{MDH}^{*}$ enzymatic activity.

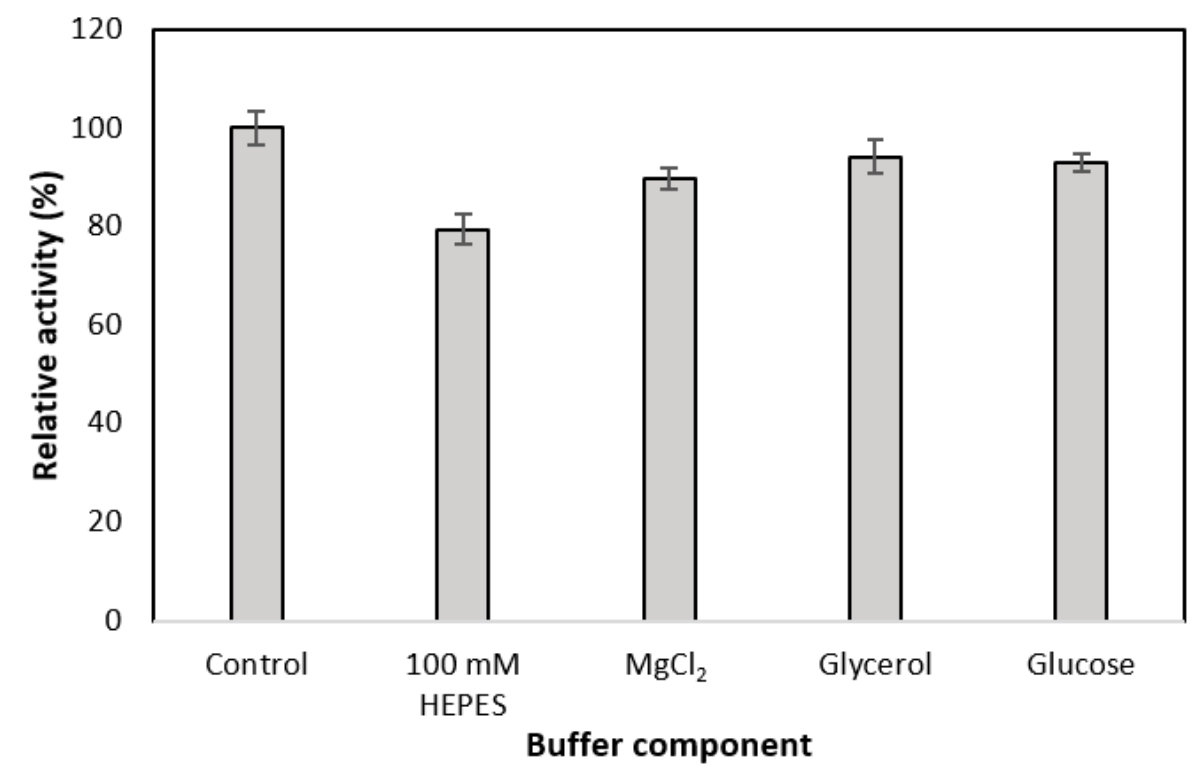

Figure 2. Effect of GDH assay buffer components on the activity of $\mathrm{MDH}^{*}$. Control is the standard $\mathrm{MDH}^{*}$ assay buffer (Table 1); the second bar represents the Control with a decreased HEPES buffer concentration (100 mM rather than $500 \mathrm{mM}$ HEPES); the third bar represents the Control with the addition of $30 \mathrm{mM} \mathrm{MgCl}_{2}$; the fourth bar represents the Control with the addition of $2.5 \%$ glycerol; the fifth bar represents the Control with the addition of $100 \mathrm{mM}$ glucose.

\subsection{Effect of Atmospheric Conditions Required by $\mathrm{MDH}^{*}$ on the Activity of GDH}

The activity of GDH was tested at $55{ }^{\circ} \mathrm{C}, 15 \% \mathrm{CO}_{2}$, and $5 \% \mathrm{O}_{2}$ atmospheric conditions in a standard GDH reaction mix. The activity of the GDH under these conditions was compared with the activity of GDH under its standard aerobic (without atmospheric 
control) assay conditions. Activity of GDH was determined not to be affected by the atmospheric conditions required by $\mathrm{MDH}^{*}$ (Figure 3).

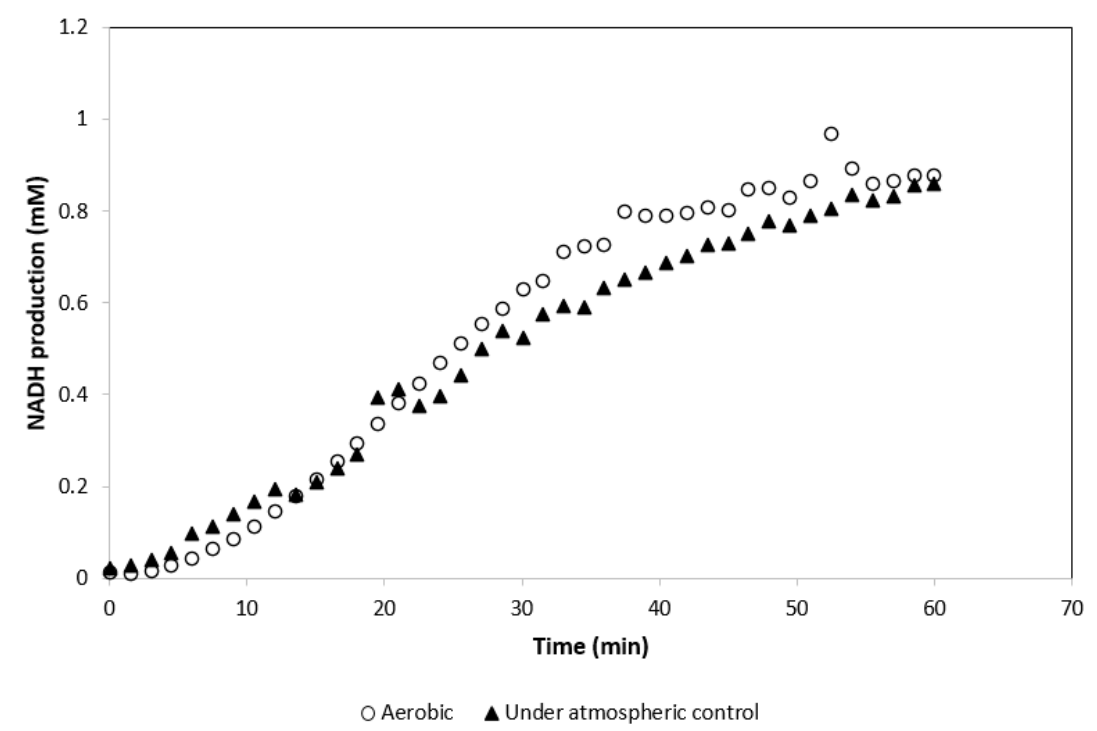

Figure 3. Activity of GDH under aerobic and $15 \% \mathrm{CO}_{2}$ and $5 \% \mathrm{O}_{2}$ atmospheric condition (results are the averages of 3 different readings, standard deviation for all conditions $\leq 0.07$ ).

\subsection{Effect of $M D H^{*}$ Assay Buffer Components on the Activity of GDH}

Having examined the effect of GDH buffer components on $\mathrm{MDH}^{*}$ activity, the effects of $\mathrm{MDH}^{*}$ buffer components were examined on the activity of GDH under $15 \% \mathrm{CO}_{2}$ and $5 \% \mathrm{O}_{2}$. The initial glucose concentration was $100 \mathrm{mM}$. Figure 4 shows that the presence of pyruvate has a significant effect on the activity of GDH. When the pyruvate concentration was $30 \mathrm{mM}$, GDH activity decreased by $96.7 \%$. Increasing the final concentration of HEPES from $100 \mathrm{mM}$ to $500 \mathrm{mM}$ decreased the activity of GDH by $15.5 \%$. When $\mathrm{MnCl}_{2}$ and $\mathrm{NaHCO}_{3}$ were added to the buffer, the activity of GDH showed an increase of $6.9 \%$ and $8.2 \%$, respectively.

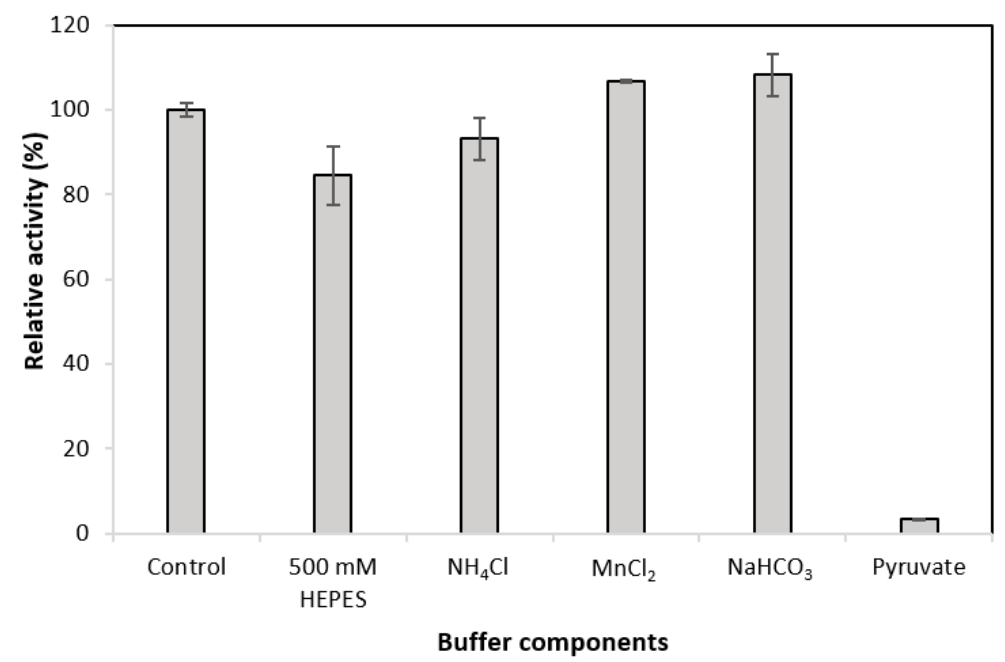

Figure 4. Effect of $\mathrm{MDH}^{*}$ assay buffer components on the activity of GDH. Control is the standard GDH assay buffer (Table 1); the second bar represents the Control with $500 \mathrm{mM}$ instead of $100 \mathrm{mM}$ HEPES; the third bar represents the Control with the addition of $5 \mathrm{mM} \mathrm{NH}_{4} \mathrm{Cl}$; the fourth bar represents the Control with the addition of $0.5 \mathrm{mM} \mathrm{MnCl}_{2}$; the fifth bar represents the Control with the addition of $85 \mathrm{mM} \mathrm{NaHCO}$; the sixth bar represents the Control with the addition of $30 \mathrm{mM}$ pyruvate. 


\subsection{Effect of Pyruvate Concentration on the Activity of GDH}

The presence of pyruvate had a substantial negative effect on the activity of GDH (Figure 4). The effect of adding pyruvate at concentrations of $0-60 \mathrm{mM}$ to the standard GDH assay buffer was therefore examined. NADH formation was recorded over $2.5 \mathrm{~h}$ and the relative activity of GDH was calculated (Figure 5). As shown in Figure 5, pyruvate concentrations above $10 \mathrm{mM}$ had a significant effect on the activity of GDH and reduced it by over $50 \%$. This was further explored by following NADH production in the first hour of the experiment with pyruvate concentrations ranging from 0-30 mM. Figure 6 shows the effect of different pyruvate concentrations on the activity of the GDH during the first hour of the experiment, whereby concentrations of $<10 \mathrm{mM}$ of pyruvate had no significant effect on the reaction.

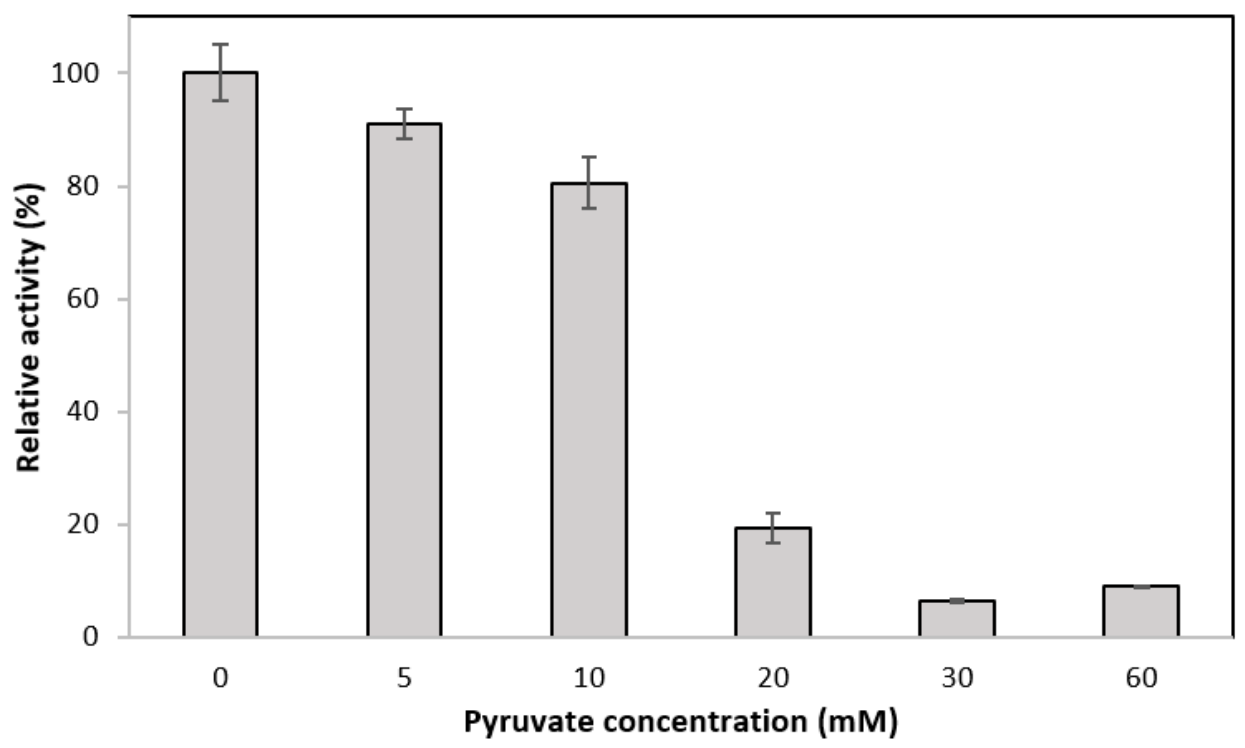

Figure 5. Effect of pyruvate concentration of the activity of GDH.

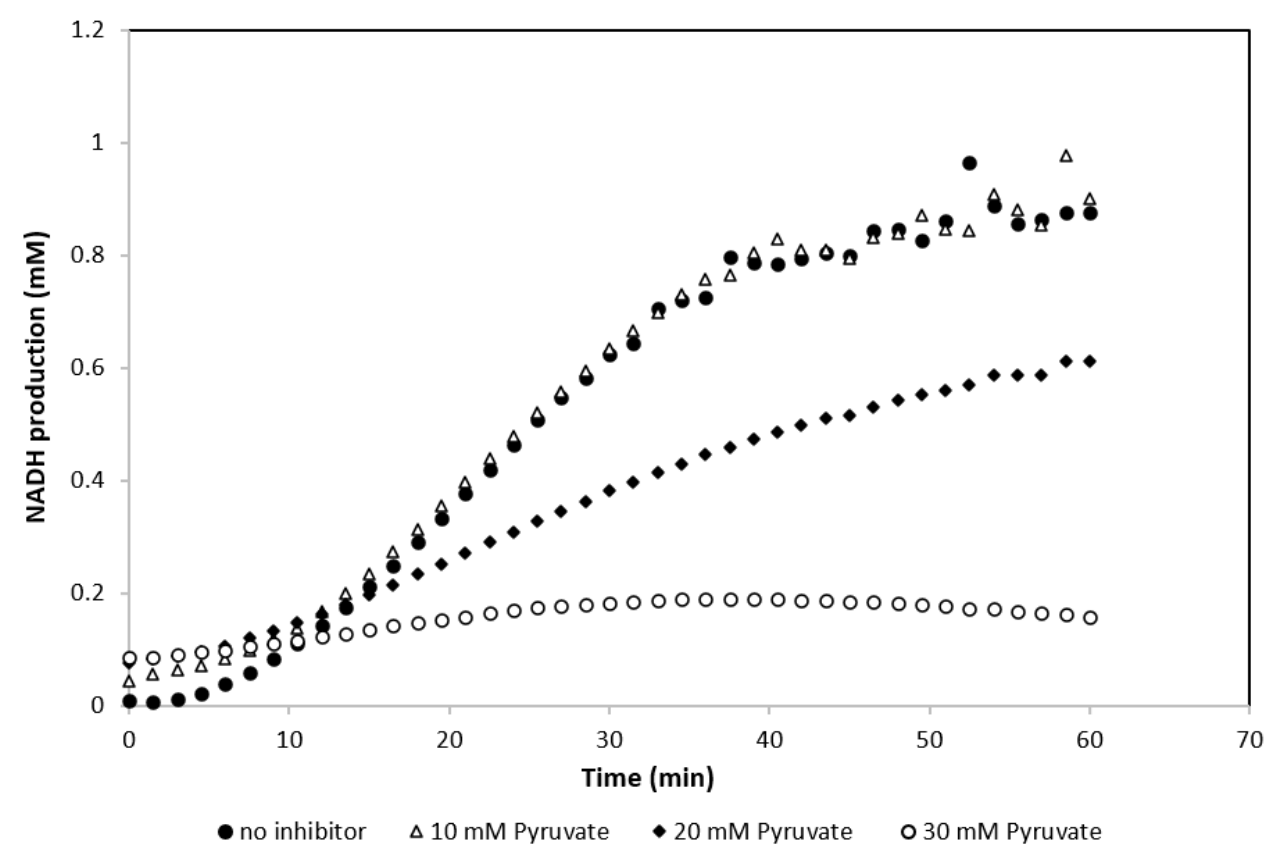

Figure 6. Effect of pyruvate concentration on NADH production by GDH using $100 \mathrm{mM}$ glucose as a substrate (results are the averages of 3 different readings, standard deviation for all conditions $\leq 0.03$ ). 


\subsection{Optimization of Atmospheric and Temperature Conditions for the Activity of Purified MDH*}

The reaction conditions for the efficient conversion of pyruvate to malate by $\mathrm{MDH}^{*}$ require high $\mathrm{CO}_{2}$ and low $\mathrm{O}_{2}$ levels. All experiments undertaken were therefore performed under standard $\mathrm{MDH}^{*}$ reaction conditions $\left(55^{\circ} \mathrm{C}, 5 \% \mathrm{O}_{2}\right.$ and $\left.15 \% \mathrm{CO}_{2}\right)$. This was further explored and optimized by testing the effects of different $\mathrm{O}_{2}$ and $\mathrm{CO}_{2}$ ratios at different temperatures on the activity of $\mathrm{MDH}^{*}$ to obtain optimal reaction conditions. A BoxBehnken design and response surface methodology were used with MATLAB 2019a, to develop a model that identified the conditions leading to maximum $\mathrm{MDH}^{*}$ activity. The values of the three chosen input variables are shown in Supplementary Table S1. The chosen temperature range of $45-65^{\circ} \mathrm{C}$ was selected on account of instrumental technical specifications and the use of a thermophilic enzyme. Fifteen independent experiments were performed to examine the effect of the experimental variables on the initial reaction rate of $\mathrm{MDH}^{*}$ activity. The initial reaction rate was calculated via the decrease in NADH concentration at the beginning of the reaction. The full data set for all 15 conditions is shown in Table 2 (and Supplementary Table S2). The highest initial reaction rate, $0.103 \mathrm{mM} / \mathrm{min}$, was detected at $65^{\circ} \mathrm{C}, 7.5 \% \mathrm{O}_{2}$, and $10 \% \mathrm{CO}_{2}$ for experiment number eight (Table 2). The maximum initial reaction rate value was calculated by the model to be $0.102 \mathrm{mM} / \mathrm{min}$, with temperature, $\mathrm{O}_{2}$ and $\mathrm{CO}_{2}$ values of $65{ }^{\circ} \mathrm{C}, 5.625 \%$ and $12.5 \%$, respectively. The experimentally obtained value and the value as calculated by the model were in close agreement. These conditions were then used for all further activity assays $\left(65^{\circ} \mathrm{C}, 5.6 \% \mathrm{O}_{2}\right.$ and $\left.12.5 \% \mathrm{CO}_{2}\right)$.

Table 2. Experimental conditions and initial $\mathrm{MDH}^{*}$ activity rates obtained with the input conditions outlined in Supplementary Table S2 and as calculated using the model *.

\begin{tabular}{cccccc}
\hline $\begin{array}{c}\text { Experiment } \\
\text { Number }\end{array}$ & $\mathbf{O}_{\mathbf{2}}(\mathbf{\%})$ & $\mathbf{C O}_{\mathbf{2}}(\mathbf{\%})$ & $\begin{array}{c}\text { Temperature } \\
\left({ }^{\circ} \mathbf{C}\right)\end{array}$ & $\begin{array}{c}\text { Initial Rate } \\
(\mathbf{m M} / \mathbf{m i n})\end{array}$ & $\begin{array}{c}\text { Initial Rate } \\
(\mathbf{m M} / \mathbf{m i n})\end{array}$ \\
\hline 1 & 2.5 & 5 & 55 & 0.068 & 0.066 \\
\hline 2 & 7.5 & 5 & 55 & 0.061 & 0.064 \\
\hline 3 & 2.5 & 15 & 55 & 0.067 & 0.065 \\
\hline 4 & 7.5 & 15 & 55 & 0.086 & 0.088 \\
\hline 5 & 2.5 & 10 & 45 & 0.030 & 0.039 \\
\hline 6 & 7.5 & 10 & 45 & 0.059 & 0.063 \\
\hline 7 & 2.5 & 10 & 65 & 0.098 & 0.095 \\
\hline 8 & 7.5 & 10 & 65 & 0.103 & 0.094 \\
\hline 9 & 5 & 5 & 45 & 0.052 & 0.045 \\
\hline 10 & 5 & 15 & 45 & 0.054 & 0.082 \\
\hline 11 & 5 & 5 & 65 & 0.076 & 0.049 \\
\hline 12 & 5 & 15 & 65 & 0.092 & 0.099 \\
\hline 13 & 5 & 10 & 55 & 0.078 & 0.086 \\
\hline 14 & 5 & 10 & 55 & 0.092 & 0.086 \\
\hline 15 & 5 & 10 & 55 & 0.088 & 0.086 \\
\hline
\end{tabular}

\subsection{Coupling $M D H^{*}$ and GDH for Cofactor Recycling}

Having identified buffer conditions that could support the activity of both enzymes, the activities and cofactor recycling capabilities of purified $\mathrm{MDH}^{*}$ and GDH were assayed within the same experiment at the optimal conditions of $65^{\circ} \mathrm{C}, 5.6 \% \mathrm{O}_{2}$ and $12.5 \% \mathrm{CO}_{2}$. Pyruvate and glucose concentrations were each adjusted to $30 \mathrm{mM}$, the concentration of HEPES was kept at $500 \mathrm{mM}$, and all other components were added to the reaction as shown in Table 1. Two different experimental setups were used to determine the success of coupling the two enzymes. 
In the first setup, changes in pyruvate concentration were examined, which would indicate the conversion of NADH to NAD ${ }^{+}$and pyruvate to malate by $\mathrm{MDH}^{*}$. The reaction was tested under optimal conditions $\left(65^{\circ} \mathrm{C}, 5.6 \% \mathrm{O}_{2}\right.$ and $\left.12.5 \% \mathrm{CO}_{2}\right)$, by the addition of $\mathrm{NADH}$. In the second setup, the same reaction mixture was used but the reaction was initiated by the addition of $\mathrm{NAD}^{+}$instead of NADH. Changes in the NADH concentration were monitored for $2 \mathrm{~h}$ with a plate reader. The final NADH concentrations were compared with an enzyme-free reaction control containing the same initial concentration of NADH as the first experimental setup (Table 3). Despite the presence of $30 \mathrm{mM}$ pyruvate, GDH still displayed activity. The NADH consumption in the first setup demonstrated the activity of $\mathrm{MDH}^{*}$. The concentrations of malate and gluconate produced by the cascade were also established by deproteinizing samples of the reaction mixture, diluting them 10 -fold, and analyzing them via HPIC. However, due to the high dilution factor, malate peaks were below the detection limit and pyruvate as the substrate was in excess; hence, small changes in concentrations were indistinguishable. However, gluconic acid production was detected in both cases, demonstrating that cofactor recycling had been achieved.

Table 3. Coupling GDH and $\mathrm{MDH}^{*}$ for cofactor recycling capabilities.

\begin{tabular}{cccc}
\hline & $\begin{array}{c}\text { Scenario 1: Presence } \\
\text { of Both Enzymes } \\
\left.\text { (GDH and } \text { MDH }^{*}\right), \\
\text { NADH as Cofactor }\end{array}$ & $\begin{array}{c}\text { Scenario 2: Presence } \\
\text { of Both Enzymes } \\
\text { (GDH and MDH }^{*} \text { ), } \\
\text { NAD }^{+} \text {as Cofactor }\end{array}$ & $\begin{array}{c}\text { Control: No Enzyme, } \\
\text { Contains Same } \\
\text { Amount of NADH } \\
\text { as Scenario 1 }\end{array}$ \\
\hline $\begin{array}{c}\text { Final NADH } \\
\text { concentration, } \mathrm{mM}\end{array}$ & $1.21 \pm 0.06$ & $1.31 \pm 0.01$ & $1.74 \pm 0.04$ \\
\hline $\begin{array}{c}\text { Gluconic acid } \\
\text { concentration, } \mathrm{mM}\end{array}$ & 8.81 & 10.45 & 0 \\
\hline
\end{tabular}

To detect malate by HPIC, $2 \mathrm{~mL}$ cascade reactions were set up and monitored via plate reader, comprising 13.2U GDH and 3.3U $\mathrm{MDH}^{*}$ under optimal reaction conditions $\left(65{ }^{\circ} \mathrm{C}, 5.6 \% \mathrm{O}_{2}\right.$ and $\left.12.5 \% \mathrm{CO}_{2}\right)$. The reactions were initiated by the addition of NADH. All experiments were carried out in triplicate under the same conditions for different periods of time. An $\mathrm{MDH}^{*}$-only reaction was run as a control (Figure 7B). The gluconic and malic acid yields from the cascade reaction were significantly higher than when $\mathrm{MDH}^{*}$ was used alone (Figure 7A). As a result, $15.96 \mathrm{mM}$ malic acid and $9.94 \mathrm{mM}$ gluconic acid were produced by the cascade reaction after $3 \mathrm{~h}$ compared to $0.309 \mathrm{mM}$ malic acid from the $\mathrm{MDH}^{*}$-only reaction. Notably, $2 \mathrm{mM}$ malic acid was produced by the dual enzyme system after $15 \mathrm{~min}$ (which is higher than the malic acid yield by $\mathrm{MDH}^{*}$ alone after a reaction time of $3 \mathrm{~h}$ ) and another high-value chemical, gluconic acid, was additionally produced by the cascade system from glucose and $\mathrm{NAD}^{+}$.

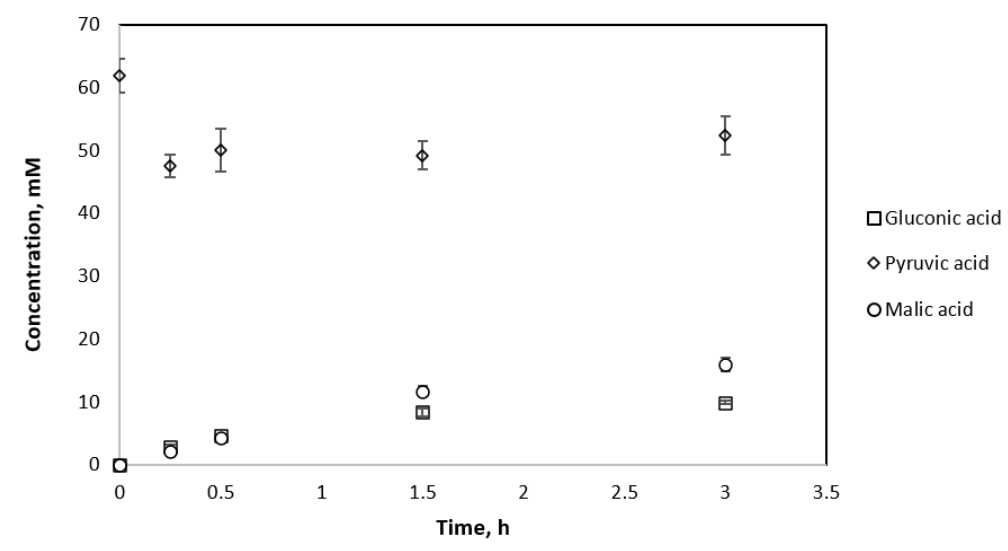

(A)

Figure 7. Cont. 


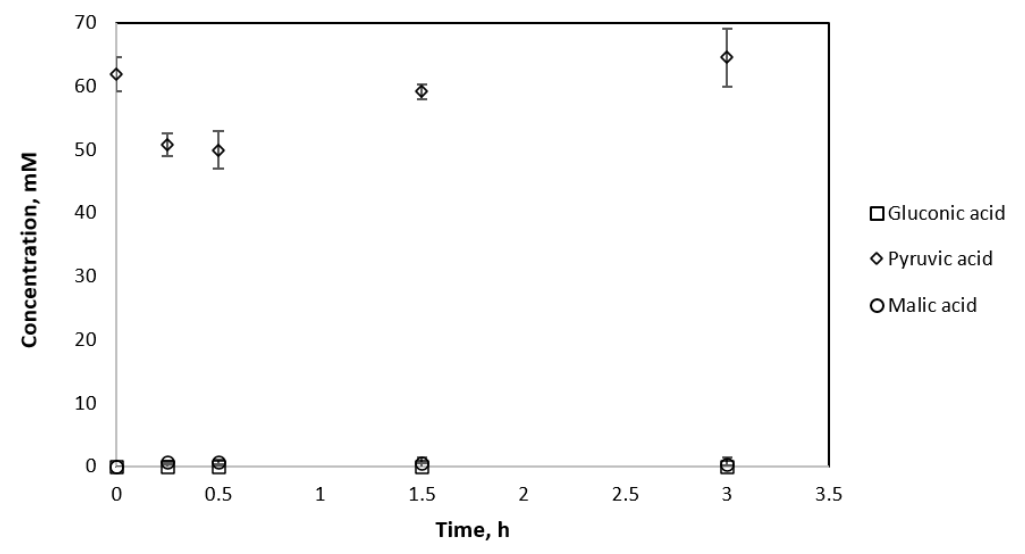

(B)

Figure 7. Substrate consumption and product formation by $\mathrm{MDH}^{*}$ and $\mathrm{GDH}(\mathbf{A})$ and $\mathrm{MDH}^{*}$ alone (B).

\section{Discussion}

To ensure a successful coupled reaction, the effects of GDH (the regeneration enzyme) reaction conditions on the activity of $\mathrm{MDH}^{*}$ (the production enzyme) were examined. The highest reduction in $\mathrm{MDH}^{*}$ enzymatic activity was caused by a decrease in HEPES buffer concentration from the standard $500 \mathrm{Mm}$ HEPES in $\mathrm{MDH}^{*}$ assays to $100 \mathrm{Mm}$ HEPES in GDH assays; the activity of $\mathrm{MDH}^{*}$ was reduced by $20 \%$ (Figure 2). The majority of enzymes require only moderate ionic strength, typically ranging between 50 and $200 \mathrm{Mm}$, but this is not the case for thermophilic enzymes which require buffer concentrations up to $1 \mathrm{M}$ [15]. The observed decrease in activity is therefore likely due to the reduction in buffer capacity which, along with any added components, can reduce the obligatory enzyme activity [16]. Aside from HEPES, the addition of other GDH assay components such as $\mathrm{MgCl}_{2}$, glycerol, and the GDH substrate, glucose, did not reduce $\mathrm{MDH}^{*}$ activity by more than $10 \%$ (Figure 2).

$\mathrm{MDH}^{*}$ activity assays were carried out under $15 \% \mathrm{CO}_{2}$ and $5 \% \mathrm{O}_{2}$ atmospheric conditions; therefore, GDH activity was assayed under atmospheric conditions required by $\mathrm{MDH}^{*}$ and activity levels of GDH were measured via the concomitant production of NADH from the oxidation of glucose to gluconate. After $60 \mathrm{~min}$, there was no significant difference between the amount of NADH produced by GDH assayed under aerobic conditions and GDH assayed under atmospheric control (Figure 3). From these findings, it was concluded that GDH is a suitable cofactor recycling partner and its reaction components do not drastically inhibit the activity of $\mathrm{MDH}^{*}$. It was concluded that GDH can be utilized effectively under altered atmospheric conditions as per the requirements of $\mathrm{MDH}^{*}$.

For a fully feasible cofactor recycling coupling, the assay components of $\mathrm{MDH}^{*}$ were also tested on the activity of GDH under atmospheric conditions. This experiment demonstrated the drastic effect of pyruvate on reducing the activity of GDH (Figure 4). This loss of activity was determined to be due to the competitive inhibition of GDH by pyruvate, because concentrations of $10 \mathrm{mM}$ pyruvate reduced GDH activity by $~ 60 \%$, and a twofold increase in pyruvate concentration increased the $\mathrm{K}_{\mathrm{M}}$ value sixfold (Supplementary Table S3). Concentrations of $30 \mathrm{mM}$ pyruvate and $30 \mathrm{mM}$ glucose were used to mitigate the issue of $\mathrm{GDH}$ inhibition by pyruvate. Cofactor recycling was demonstrated when using $\mathrm{NAD}^{+}$or $\mathrm{NADH}$ as cofactors in the presence of both GDH and $\mathrm{MDH}^{*}$ (Table 3).

In conclusion, we have demonstrated cofactor regeneration within a closed system of two thermophilic enzymes. The work carried out here sets the foundation for this concept to be explored further with longer reaction times and further optimization of reaction conditions. The redox neutrality of the two enzymes may now be exploited further by expanding the number of enzymes in the cascade system. Further optimization regarding the separation of the products can also be explored. Immobilization of the coupled enzymes will provide potential solutions to issues linked with enzyme cost and stability $[17,18]$ 
and for catalyst recycling on an industrial scale [19], offering advantages of both economy and sustainability.

Supplementary Materials: The following are available online at https:/ /www.mdpi.com/article/10 $.3390 /$ app 11114877 /s1, Figure S1: Schematic representation of redox balanced cascade with cofactor recycling, Figure S2: Effect of atmospheric conditions and the reaction temperature on the initial rate of $\mathrm{MDH}^{*}$, Table S1: Atmospheric condition independent variables and their values, Table S2: Box-Behnken design for 3 factors with 3 center points, Table S3: Change in kinetic parameters of $\mathrm{GDH}$ in the presence of different pyruvate concentrations.

Author Contributions: Conceptualization, R.M., P.K. and R.M.B.; methodology, R.M. and P.K.; formal analysis, R.M., P.K. and R.M.B.; resources, R.M.B.; writing-original draft preparation, R.M., P.K. and R.M.B.; writing—review and editing, R.M., P.K. and R.M.B.; funding acquisition, R.M.B. All authors have read and agreed to the published version of the manuscript.

Funding: This research was funded by the Biotechnology and Biological Sciences Research Council (BBSRC) through the Global Challenges Research Fund Project, CAPRI-BIO (BB/P022685/1). R.M. was supported by a BBSRC training grant with Chemoxy Ltd. (BB/M016668/1). The APC was funded by BBSRC.

Conflicts of Interest: The authors declare no conflict of interest.

\begin{abstract}
Abbreviations
$\mathrm{NADP}^{+}$—nicotinamide adenine dinucleotide phosphate; $\mathrm{NAD}^{+}$—nicotinamide adenine dinucleotide; $\mathrm{MDH}^{*}$ — triple mutant malate dehydrogenase; GDH—glucose dehydrogenase; FDH—formate dehydrogenase; IPTG—isopropyl $\mathrm{B}$-D-1-thiogalactopyranoside; $\mathrm{MgCl}_{2}$-magnesium chloride; $\mathrm{Ni}$ NTA — nickel nitrilotriacetic acid; $\mathrm{BCA}$ — bicinchoninic acid assay; $\mathrm{NH}_{4} \mathrm{Cl}$ - ammonium chloride; $\mathrm{MnCl}_{2}$-manganese chloride; $\mathrm{NaHCO}_{3}$ —-sodium bicarbonate; $\mathrm{HPIC}$ - high-pressure ion chromatography; SDS-PAGE—sodium dodecyl sulphate-polyacrylamide gel electrophoresis.
\end{abstract}

\title{
References
}

1. Jang, Y.-S.; Kim, B.; Shin, J.H.; Choi, Y.J.; Choi, S.; Song, C.W.; Lee, J.; Park, H.G.; Lee, S.Y. Bio-based production of C2-C6 platform chemicals. Biotechnol. Bioeng. 2012, 109, 2437-2459. [CrossRef] [PubMed]

2. Erickson, B.; Nelson, J.E.; Winters, P. Perspective on opportunities in industrial biotechnology in renewable chemicals. Biotechnol. J. 2012, 7, 176-185. [CrossRef] [PubMed]

3. Dudley, Q.M.; Karim, A.S.; Jewett, M.C. Cell-free metabolic engineering: Biomanufacturing beyond the cell. Biotechnol. J. 2015, 10, 69-82. [CrossRef] [PubMed]

4. Singhvi, M.; Gokhale, D. Biomass to biodegradable polymer (PLA). RSC Adv. 2013, 3, 13558-13568. [CrossRef]

5. Guterl, J.-K.; Sieber, V. Biosynthesis “debugged”: Novel bioproduction strategies. Eng. Life Sci. 2013, 13, 4-18. [CrossRef]

6. Bozell, J.J.; Petersen, G.R. Technology development for the production of biobased products from biorefinery carbohydrates-the US Department of Energy's "Top 10" revisited. Green Chem. 2010, 12, 539-554. [CrossRef]

7. Wang, X.; Saba, T.; Yiu, H.H.P.; Howe, R.F.; Anderson, J.A.; Shi, J. Cofactor NAD(P)H regeneration inspired by heterogeneous pathways. Chem 2017, 2, 621-654. [CrossRef]

8. Rollin, J.A.; Tam, T.K.; Zhang, Y.H.P. New biotechnology paradigm: Cell-free biosystems for biomanufacturing. Green Chem. 2013, 15, 1708-1719. [CrossRef]

9. Guterl, J.K.; Garbe, D.; Carsten, J.; Steffler, F.; Sommer, B.; Reiße, S.; Philipp, A.; Haack, M.; Rühmann, B.; Koltermann, A.; et al. Cell-free metabolic engineering: Production of chemicals by minimized reaction cascades. ChemSusChem 2012, 5, $2165-2172$. [CrossRef]

10. Petroll, K.; Kopp, D.; Care, A.; Bergquist, P.L.; Sunna, A. Tools and strategies for constructing cell-free enzyme pathways. Biotechnol. Adv. 2019, 37, 91-108. [CrossRef] [PubMed]

11. Chenault, H.K.; Simon, E.S.; Whitesides, G.M. Cofactor regeneration for enzyme-catalysed synthesis. Biotechnol. Genet. Eng. Rev. 1988, 6, 221-270. [CrossRef] [PubMed]

12. Hollmann, F.; Arends, I.W.C.E.; Holtmann, D. Enzymatic reductions for the chemist. Green Chem. 2011, 13, 2285-2314. [CrossRef]

13. Morimoto, Y.; Honda, K.; Ye, X.; Okano, K.; Ohtake, H. Directed evolution of thermotolerant malic enzyme for improved malate production. J. Biosci. Bioeng. 2014, 117, 147-152. [CrossRef] [PubMed]

14. Karagoz, P.; Mandair, R.; Manayil, J.C.; Lad, J.; Chong, K.; Kyriakou, G.; Lee, A.F.; Wilson, K.; Bill, R.M. Purification and immobilization of engineered glucose dehydrogenase: A new approach to producing gluconic acid from breadwaste. Biotechnol. Biofuels 2020, 13, 100. [CrossRef] 
15. Vieille, C.; Zeikus, G.J. Hyperthermophilic enzymes: Sources, uses, and molecular mechanisms for thermostability. Microbiol. Mol. Biol. Rev. 2001, 65, 1-43. [CrossRef] [PubMed]

16. Bisswanger, H. Enzyme assays. Perspect. Sci. 2014, 1, 41-55. [CrossRef]

17. Kumar, P.; Ryan, B.; Henehan, G.T.M. $\beta$-Glucosidase from streptomyces griseus: Nanoparticle immobilisation and application to alkyl glucoside synthesis. Protein Expr. Purif. 2017, 132, 164-170. [CrossRef] [PubMed]

18. Misson, M.; Zhang, H.; Jin, B. Nanobiocatalyst advancements and bioprocessing applications. J. R. Soc. Interface 2015, $12,20140891$. [CrossRef] [PubMed]

19. Sheldon, R.A.; van Pelt, S. Enzyme immobilisation in biocatalysis: Why, what and how. Chem. Soc. Rev. 2013, $42,6223-6235$. [CrossRef] [PubMed] 